\title{
What is Anti-Enlightenment?
}

\author{
O que é o Anti-Esclarecimento?
}

\section{Diana Gasparyan*}

National Research University Higher School of Economics, Moscou, Russia

\begin{abstract}
It is well known that postmodern philosophy primarily focuses on the experience of re-thinking of the ideals of the Enlightenment. An extensive Post-Enlightenment turns into Anti-Enlightenment development is, in fact, the true underlying concept lying at the heart of this philosophy. In other words, postmodern philosophy primarily focuses on the experience of re-thinking of the ideals of the Enlightenment. However the point from which the Enlightenment is being criticized can be described fairly accurately. Ultimately, the prefix "anti" can be interpreted in two ways. The Anti-Enlightenment is, on the one hand, weeping over the failed Enlightenment, but on the other hand, a rebellion against the Enlightenment, which, though having been accomplished, fell short of hopes and expectations associated with it. The current research explores this question.
\end{abstract}

Keywords: Enlightenment. Anti-Enlightenment. Postmodern Philosophy.

* DG: Doutora em filosofia, e-mail: anaid6@yandex.ru 


\section{Resumo}

É bem conhecido que a filosofia pós-moderna se concentra principalmente na experiência de re-pensamento dos ideais do lluminismo. Uma extensa virada pós-iluminista dentro do desenvolvimento Anti-esclarecimento é, de fato, o verdadeiro conceito subjacente que encontra-se no coração desta filosofia. Em outras palavras, a filosofia pós-moderna se concentra principalmente na experiência de re-pensamento dos ideais do lluminismo. No entanto, o ponto a partir do qual o lluminismo está sendo criticado pode ser descrito com bastante precisão. Em última análise, o prefixo "anti" pode ser interpretado de duas maneiras. $O$ anti-lluminsmo é, por um lado, o lamentar sobre o lluminismo falido, mas por outro lado, uma rebelião contra o lluminismo que, pensando-se ter se realizado, recai na ausência de esperanças e expectativas com ele associado. A presente pesquisa explora essa questão.

Palavras-chave: Esclarecimento. Anti-Esclarecimento. Filosofia Pós-moderna.

\section{Introduction: postmodern project as post-enlightenment project}

A man, at least partly enlightened with the knowledge of contexts, which in their combination gave rise to the collective name "Postmodern Philosophy," is well aware that an extensive PostEnlightenment turns into Anti-Enlightenment development is, in fact, the true underlying concept lying at the heart of this philosophy. In other words, postmodern philosophy primarily focuses on the experience of re-thinking of the ideals of the Enlightenment.

How should the objectives of the Anti-Enlightenment be understood? Ultimately, the prefix "anti" can be interpreted in two ways. On the one hand, from the prospective of Rousseau's philosophy, it could be interpreted as a kind of call "Go back to barbarism!" On the other it could mean that the attempt to educate the West has failed, while hinting that the Enlightenment has never been truly accomplished. We should note, however, that criticism of the Enlightenment's agenda has a well-defined metaposition and a set of tenets associated with it; actually, the point from which the Enlightenment is being criticized 
can be described fairly accurately. This is the point where the idea that the Enlightenment was not quite enlightening stems from. The AntiEnlightenment has a dialectical imprint on many of its aspects: enlightenment of the Enlightenment turned out to be the Anti-Enlightenment (by analogy with the "negation of the negation" (Hegel 1977), which, though not being a return to the previous point, has moved to a new synthetic level, as a result of its "cancellation").

Then, the Anti-Enlightenment is, on the one hand, weeping over the failed Enlightenment, but on the other hand, a rebellion against the Enlightenment, which, though having been accomplished, fell short of hopes and expectations associated with it. This is also an affirmation that the Enlightenment has some "back" or "shady" side, a kind of "devil's conditions" - the cost of its alleged benefits. The Anti-Enlightenment, in its most radical version, declares: the Enlightenment is a dangerous and harmful agenda in the form, in which it sets the course of development for the Western European civilization from Plato to the present day, since its consequences are devastating and prospects are frightening. Then, the idea of enlightening the Enlightenment shall mean to detect and disclose all of its secrets. In the end, people have a right to know what the true cost of their enlightenment is - the "rights to know".

However, before we continue our exploration, we should answer the question, "What is the Enlightenment?" The best answer was given by Kant, "The Enlightenment is the courage to use your own understanding" (Kant 1996: 12). A person can consider himself to have reached a maturity if one day he dared to use his own mind without anybody's guidance (without the help of the "Other" in the terminology of postmodern philosophy). Otherwise, even if a person reaches an old age, he would still remain a "minor". "The Enlightenment is a way for a person to end his minority, in which he stalls due to his own fault. Minority is inability to use own intellect without a guidance from someone else. Minority due to own fault is a phenomenon that is caused not by the lack of intelligence, but by the lack of determination and courage to use it without guidance from someone else. Sapere aude! - have the courage to use your own mind! - is, therefore, the motto of the Enlightenment" (Kant 1996:12). The definition offered by 
Kant would become absolutely canonical, and, if one tries to contest the Enlightenment, it would largely mean nothing else, but an attempt to challenge Kant's definition.

\section{What is wrong with Enlightenment}

Primary objections voiced by postmodernists concern this very most general statement. They argue that the idea of the "mind's maturity," despite its overall loftiness, is merely a utopia. Mind was not created as something self-contained. For it to attempt mental reasoning, it must first go through a series of mediations: mediation through language, mediation through values and, finally, mediation through the distinction between Reason and Unreason. Each of the mediations is a sum of many elements, some of which are not directly related to "pure reason" and smooth operation of the reasoning system. All these mediations embody "conceptual ballast," which, along with formal rules, structuring mind's operation, bears certain underlying connotations, which, being imposed on mind through the very mechanism of mediation, subject it to dependency. For example, the language, which the mind needs to do mental work, because thinking is, initially, an experience of conversing with yourself, introduces the semantics, which is specific to each given language. Therefore, a mind that possesses knowledge of different languages operates differently. Thus, representatives of different cultures go through the mental process differently. This will occur not because the minds of some of them are mature and the minds of others are not, but because, referring to the mind, we refer to the culture, which has shaped it, and that, if to follow Kant's teaching, is a violation of the principle of the mind's self-containedness. And in turn, a decision where the line between intelligence and insanity should lie is not a product of the mind's operation, but is generated based on what is considered a norm and a deviation from it. And this, in many respects, is a statistical problem, i.e., a problem referring us to the extremely volatile and tendentious research practice. In this sense, the "mind of its own," according to postmodernists, presents a kind of 
an oxymoron - the mind can never be "its own," as it does not belong to itself since the source that shapes it is external. In short, a postmodern interpretation of Kant's statement should sound like this, "Have the courage to admit that you never use your own mind".

However, the idea of the "own mind" conceals yet another deception. Let's suppose that the mind can rely on itself. Let's also imagine that its autonomy and sovereignty are quite achievable. What consequences would it have for the Enlightenment? Rather dangerous - the mind, which relies only on itself, is in some respect even worse than the mind relying on the aid of guides and advisers. "Pure mind" is defined as such precisely because it is not contaminated with any superinducements. There is also an unfilled mind - it lacks content, which is a guarantee of its impartiality and, proclaimed by the Enlightenment, criticality. But the mind that is unfilled, also seems to be unintelligent because, being void of content (e.g., value-neutral), it would most probably be unable to evaluate contents introduced to it. If it constitutes its own basis, based on what could it then recognize a difference between the unlawfulness of the extermination of mentally ill, maintenance of whose lives is deemed irrational and the economic feasibility of recycling of waste, the preservation of which is also irrational? Would then the mind be able to solve this problem if it remains "pure" and self-sufficient? And wouldn't then the notions "lack of premises" and "lack of principles" be synonymous when rationality is spoken of?

Ultimately, postmodernism attempts to display that reliance on "own mind" is either impossible, or fraught with danger to slide into cynicism. If we apply this reasoning to specific historical events, which, as we have said, challenged sinlessness of the Enlightenment, we should also point out that such phenomenon as National Socialist aberration should have been clearly explained in the first place. Strictly speaking, if we want to get at least some clarification, we are free to choose between two possible answers. Either we should say that, "the world was rational enough to allow Nazism spread," or that "the world was too irrational to prevent Nazism from spreading". By choosing one of the answers, we recognized Nazism as either a rational, or an irrational doctrine. What answer would postmodern 
philosophers choose? Vast majority of them chooses the first answer (though, they always readily acknowledge the identicality of the two). A significant part of postmodern authors is willing to sign a statement that "Nazism was the apotheosis of rationality".

However, if there is little difference between the rational and irrational, it is even worse. But no matter how hard we try to search for signs of irrationality in the concepts of world domination, or the necessity to destroy unproductive or defective citizens, or the idea of accounting for the racial differences, we are unlikely to succeed. All the concepts constituting the essence of the ideology of totalitarianism and Nazism seem perfectly logical and do not sound crazy. Rather, the madness is in the belief that reasonable and humane are identical.

A conclusion of prime importance, related to the criticism of the agenda of the Enlightenment, can be drawn from this reasoning. It is important for postmodernism, which, as we have said, aims to enlighten the Enlightenment, to demonstrate that an appeal to such bundles of ideas, as "the Enlightenment-humanism - rationality", "sensibleness - morality - benevolence," "courage to use your own mind - the courage to be merciful," etc. is naive and dangerous.

As Foucault writes, "I think that we should not succumb to this intellectual and political blackmail - "to be in favor or against the Enlightenment?" - we should avoid historical and moral confusion mixing the topic of humanism and the problem of the Enlightenment... There once was humanism that criticized Christianity or religion in general; there was Christian humanism, which was, in turn, contrasted with the ascetic and much more theocentric humanism (as it was in the 17th century). In the 19th century there was humanism demonstrating disbelief, hostility and criticism toward science, and, at the same time, there was yet another humanism, which, on the contrary, put its hopes on the same science. Marxism posed as humanism. The same is true for existentialism and personalism. There was a time when humanistic values were presented as the values of National Socialism and when the Stalinists would also insist that they were humanists. A conclusion that can be drawn is not that everything claiming to be humanism should be denounced, but that the topic of 
humanism is too pliable, too heterogeneous, too vague to serve as an axis of reflection" (Foucault 1984: 143).

If we believe that every time when we listen to the voice of our reasoning we hear the voice of our own conscience, we are just outright wrong. Mind doesn't warrant it and there is no automatically attainable moral enlightenment even if we refer to our mind regularly. Though, the notion "to be enlightened" also involves a mandatory component of ethics; "to be the most rational" and "to be the most moral," however, do not have the same implications. But the bundles of ideas, similar to those discussed, simply relieve us from any ethical responsibility for our decisions and actions by promising us an allegedly simplified and clarified choice of actions.

However, claims of postmodernists do not end there. Another accusation brought against the Enlightenment is that it is not politically impartial or that it has a plain tendency toward "double standards". Let's ask a simple question: how the ideals of the Enlightenment agree with the real civil practice? In other words, what does it mean to be an "enlightened person," i.e., to be able to use your mind and "be a citizen of your country," i.e., follow the laws of the state? The Romans, who gave us eidetic samples of the statehood and the law said, "Dura Lex sed Lex." Unquestioned adherence to the law is an essential virtue of man and citizen. Are the concepts of the Enlightenment in harmony with this statement, or the viewpoint of an enlightened person would disagree with his civic duty? To start with, we should try to see whether there is some conflict here. On the one hand, the Enlightenment teaches us not to take anything for granted, not to submit to the authority, to fear nothing, to resort to our own mind in any circumstances, always assume a critical attitude and, if necessary, to boycott that, which we strongly disagree with. On the other hand, a person, being a citizen and subject of the law, must not reason and contemplate, but act in accordance with the laws of the state. As we can see there is some apparent conflict, or at least, a difference in the viewpoints. Which of these two life strategies would be suitable for an enlightened person? According to Kant, to avoid conflicts and misunderstandings, it is necessary to distinguish the so-called "private application of reason" and "public application of 
reason". Private application of reason is required when we, as subjects of law and citizens of the state, perform our ordinary civic duty and obligations imposed on us by the society. For example, when we pay taxes, go to work, or vote in elections, we apply our reason in a private way. In the case of public use of reason, we, in the time free from our professional and civic duties, can use our right to vote and the freedom to express our opinion. For example, if I go out to support a rally in defense of someone's interests, I apply my reasoning in a public way. The subtlety of this difference is that at the level of a private application of reason, a human, no matter how profoundly he sympathizes with the principles of the Enlightenment, is not free to express his opinion if it is contrary to the accepted norms. As a possessor of the private mind, one should not use either words or actions to express his disagreement with the existing order. "I call it a private application of reason, when a person carries out civil service duties imposed on him. For some matters, affecting the public interests, there should be a mechanism, by the means of which, certain members of society could behave passively for the government to be able, through the artificial achieved unanimity, direct them to carry out public purposes or at least prevent them from destroying these purposes. Here, of course, there is no place for reasoning; here there is place for obedience" (Kant 1996: 131). But such severe restrictions could persuade us that a man of the Enlightenment is not a free and autonomous individual, but rather a slave. Kant helps us understand that this is certainly not the case. Unlike a slave, a man of the Enlightenment has an opportunity to publically use his reason, by virtue of which, he is free to express his opinion and his attitude toward the authorities, no matter what that attitude is like.

To better understand Kant's logic, let's look at an example that will clearly shows Kant's motivations in the issue concerning the division of the reason into two types of applications. Suppose we disagree with the fiscal policy of our state (taxes are unjustified and instead of replenishing the public budget, funds are used for personal expenses of officials). What should I do in this situation? Kant's answer states: continue to pay taxes. I have no right to boycott the actions 
of the authorities on the distribution of the tax burden even if I am strongly indignated by them. But I can, and even in a sense am obliged to express my opinion denouncing the abuse of the authorities in any public form. I can participate in meetings, write incriminating articles and voice my outrage from the rostrum, but I must not evade taxes out of a mere belief that I can protest in this way. The development in the Kantian reasoning is understandable - if everyone evades taxes only on the basis of their disagreement with the current legislation, the society would quite quickly collapse. When protesting, we must not discontinue exercising our civil obligations, because, first of all, innocent citizens might be affected as a result, and secondly, there could be chaos so pandemonium, that it will be impossible to impose any order.

Such logic angers and irritates the majority of representatives of post-modern philosophy. They perceive Kant's point of view as cowardly and slavish demonstration of subservience to the authorities and loyalty to any of their actions. It is also viewed as a kind of symbolic sign of profound hypocrisy, which marks the entire Enlightenment. "... the priest must give his sermon to the students studying the law of God and to his congregation according to the church order, because these are the terms of his appointment to the position. But as a scientist, he is absolutely free, and that, moreover, even is his duty - to inform the public of all his carefully considered and well-intentioned thoughts about errors in the church's order as well as of his suggestions on the best organization of religious and church affairs. There is nothing unacceptable in it that could torment his conscience" (Kant 1996: 135). Maxim, which prescribes us to "reason only under the condition of unquestioned obedience," casts a shadow on the ideals of rationality, making us suspect that the reason serves only the most powerful. In particular, in his work "What is Enlightenment?" Kant, as a Prussian subject, openly supports the policy of the then King of Prussia Frederick the Great, to whom, in fact, is attributed the remark that Kant is ready to announce the following motto as the motto of the Enlightenment, "Argue as much as you want and about anything, but obey!" "In this respect our age is the age of enlightenment, or the century of Frederick. However, only he, who is enlightened himself, is not afraid of his own 
shadow, but at the same time keeps a well-disciplined and numerous army for the protection of public safety and can say that, which the Republic wouldn't dare: Argue as much as you want and about anything, but obey!"' (Kant 1996: 136).

Ultimately, postmodernists will say - the Enlightenment only enlightens us in that the Law appears to be a meaningless mechanism that must be unquestionably obeyed. If we use Kant's terminology, the Law simply appears to be a noumenal force and its demands coincide with the noumenal moral imperatives. In other words, the Law does not belong to the field of the empirical, and we have no right to interfere with its work, and, for example, express our civil protest through actions, e.g., boycott inappropriate actions of the authorities, or to disobey the orders, which we believe are illicit in nature. We can be enlightened citizens, but only if we unconditionally accept the terms of existence of the imperatives of power, "obey simply because you must obey". Such bald statements, made by eminent classical philosophers insisting that it is preferable to not argue with the power, post-modernist philosophers noticeably lose their respect for the authority of the classics. They continue emphasizing that one should use any available means to express his civic position - from spontaneous riots to orchestrated coups.

Kant was not the only thinker, who had a discrepancy between "word and deal". Another philosopher who made no less a contribution to the development of critical ideals of rationality, Descartes, gives us another example of "hypocrisy". In his "Discourse on method" in the first rule of the method (the famous rule of Cartesian doubt) we read: “The first was never to accept anything as true if I didn't have evident knowledge of its truth: that is, carefully to avoid jumping to conclusions and preserving old opinions, and to include in my judgments only what presented itself to my mind so vividly and so clearly that I had no basis for calling it in Question" (Descartes 1960: 46).

However, already in the next Chapter entitled "What are the rules of morality, extracted from this method", Descartes makes the following moral prescriptions: "The first was to obey the laws and customs of my country, holding constantly to the religion in which by God's grace I had been instructed from my childhood, and governing 
myself in all other matters - i.e. all the ones not settled by the law of the land or my religion - on the basis of the most moderate and least extreme opinions, the opinions commonly accepted in practice by the most sensible of the people with whom I would have to live. For I had begun at this time to count my own opinions as worthless, because I wanted to examine them all, and didn't see how I could do better than in the meantime to follow those of the most sensible men. And although the Persians or Chinese may have men as sensible as any of ours, I thought that it would serve me best to be guided by those with whom I was going to live..."(Descartes 1960: 53).

Post-modern philosophy, however, would not be a true philosophy were it not trying to find an answer to the question of why the project of the Enlightenment is only somewhat revolutionary. It should not be in any case linked with the personal qualities of the mentioned above classical philosophers, their lack of courage, immature citizen's position or lucrative interests. Rather, the cause must be sought in the Enlightenment itself. It is necessary to analyze what tasks it "actually" performed and why so many outrageous things were happening in the 20th century under its influence. The answer to this question lies in the fact that the Enlightenment was and, in a sense, is the official ideology of the authorities. The Enlightenment is a discourse of the authorities, i.e., it contains everything required for its support.

Firstly, the idea of total control was inherent in the Enlightenment, which is not surprising at all, since this is precisely how mind works to understand everything, which means to be in control. Secondly, the Enlightenment, albeit implicitly, placed its stake on a transcendental subject: it was his mind that they focused on when spoke of the "courage to use your mind".

However, according to Kant, a transcendental subject is the one, who conforms to the Western European concept of rationality; representatives of other cultures, on the other hand, do not fit well in its framework. Thirdly, the Enlightenment, as we have seen, provided an illusion of freedom of expression, but did not pose any serious threat to the authorities. 
From this quite clear arises that, which the Europe had gotten by the middle of the 20th century: (1) totalitarianism as an obsessive idea of total control and supervision, (2) an anthropological principle that gave rise to the definition of "man", according to which, half of the earth's population would not fit into the category of "humans", (3) loyalty to the government, i.e., when the mind is limited so that it can only produce speeches, not actions.

\section{This deceptive mind...}

It is not surprising then that when we try to analyze unsuccessful outcome of the Enlightenment, we, first of all, question the mind and the ideals of rationality which the European culture so wholeheartedly entrusted itself to. From this point on we should subject the mind to the closest possible scrutiny and should be extremely vigilant in order not to fall victims of yet another false charm. If we keep this idea in mind, then the whole history of postmodern philosophy will appear to us as a kind of global and uncompromising protest against the infallibility of the mind, a protest denouncing the "rational" not only because of its excessive self-praise but also because of its profound anti-human nature. This task will be attempted in the present paper.

The main reproach put forward against the rational is that the mind, if we use the definition provided by ones of the passionate critics of European rationality Horkheimer and Adorno, is "instrumental". "Instrumentality of the mind" should be understood literally - the point at stake is that the mind is nothing more than just a tool (Adorno, Horkheimer 2002). Mind's work is limited only to the processing of that which was generated without its slightest engagement. Its activities are well defined by Cl. Levi-Strauss (Levi-Strauss 1963). Using the following wording he defines the structuralist unconscious - it is "always void of content" or, more precisely, it is as alien to images as the stomach is alien to food passing through it. Being an organ of a specific function, it is limited only to the imposition of structural laws ... on ... the elements fed from other places". Thus, the "instrumentality" of the 
mind implies its fundamental servicing nature - the mind is indifferent to the contexts it can be applied to.

But is it that bad that the mind is indifferent to the contexts populating it? This peculiarity of the mind was known to classics at least since the times of Kant's transcendental philosophy the mind has been referred to as the "pure mind" - an organ whose activities are limited to the processing of external contexts in accordance with certain rules ${ }^{1}$. To immediately clarify this topic and to better understand the underlying implication of the criticism of rationality, the following should be mentioned. Such criticism is pointed not so much at the properties of the mind as at hopes that classical philosophy sets on the mind. In classics the mind poses as something sacred since it is believed that it sanctifies everything it is applied to. If some reasoning is rational, then it is true; if an action is rational, it is then moral; if God exists, then it coincides with pure rationality, etc. It is against these epithets glorifying rationality that postmodernism rebells against. However, its critical work was reduced to something insignificant: it would simply warn us that we should not get too excited about the gifts of mind. If we totally obey the mind, we risk being left with nothing. If we choose to follow the path of the rational all the way through, we will be faced with a bitter disappointment at the end of our ascending - it would assail us turning into an everlasting absurd.

Let us try to ascertain the veracity of these instructions.

So we pointed at the mind's instrumental, i.e., applied nature and promised to explain what it's guilty of, as being such. Let's assume its work really comes down to the taxonomy, harmonization and connection of elements as well as to bringing them in compliance with the rules of processing and elimination of contradictions, etc. In other words, let's suppose that the only adequate activity the mind is able to be engaged in is limited to the assurance of coherence (internal

1 Kant does not support skeptical conclusions because of the detected paranormal abilities of the mind. At the last moment he "saves" the mind by indicating the true causes of its failure. Firstly, the antinomies arise out of attempts of the mind to go "beyond any possible experience," in other words, to get answers to the ultimate questions. And secondly, these antinomies are successfully solved if they are properly attributed to the relevant worlds - a thesis is true in the phenomenal world while an antithesis - in the noumenal. And this is how antinomies are neutralized. 
consistency) of thoughts. But that as a minimum implies that the mind bears no responsibility for what precisely it systematizes and harmonizes. For example, we cannot prove that "selfishness is both good and bad" or that "the oppression of the weak is both right and wrong," because these perceptions are absolutely unreasonable. But who could say that we are unreasonable if we could prove that the oppression of the weak and selfishness are quite beneficial and should be implemented, moreover since it is not difficult to prove that? The conclusion is that the mind guards only the form but by no means the content, and since there is no limit to the variation of contents, the mind turns out to be not a very selective creation. The accusation of the lack of principles is, therefore, constitutes the first attack of postmodernism against the infallibility of the mind.

The second accusation largely related to the first one is against the mind's cynicism which lies in the fact that the mind can prove anything including contradicting statements. Kant was one of the first to demonstrate structural cynicism of rational. In his antinomies the mind successfully proves two mutually exclusive philosophical statements (thesis and antithesis). However, the mind is far from rejoicing over its omnipotence. Rather it is confounded as it is celebrating a Pyrrhic victory - the mind able to prove that both " $\mathrm{A}$ " and "anti- $\mathrm{A}$ " are true is a sick mind ${ }^{2}$. Ultimately, even sophists and skeptics knew of this "weak point" of rational. The former opposed Plato - the first true metaphysician who utterly entrusted himself to the mind. The latter described the mind as being "izostenic" - the mind is like a shoulder yoke that first leans towards one statement as to the true one then to the opposite statement as also true. However, if the mind is able to prove ultimately anything, it would be proving something that pleases someone or something that is "suitable to the most powerful" as the sophist Thrasymachus Sokratu put it (Plato 2001: 86). Thus, intelligence is cynical and those who want to make the mind a servant to themselves would always find a way to take advantage of the situation. In this case, anything and anybody - ideologies, the unconscious, any discourses

2 This was the Nietzschean principle of the "master's morality" - the morality, which serves only itself. 
- can pose as the parties interested in the mind's compliance. When we use the mind reasonably, we can prove virtually anything we want. The third charge against the mind is that being a purely formal creation as far as its form is concerned it is not always easily distinguished from folly. Michel Foucault is a master of such demonstrations. Here is an excerpt from his History of Madness in the Classical Age: "[...] Lusitan describes the healing of one melancholic who considered himself forever cursed in his earth's life for having committed great sins. Since it was impossible to convince him through reasonable persuasions that he can still save his soul, they agreed with his delusions and showed him an angel in a white robe with a sword in his hand, who having given the melancholic a severe reprimand announced that his sins were forgiven (Foucault 1997: 330-331).

Even in this example we can clearly see... part of the "treatment course". Implementation in a form of an image is not satisfactory enough; it is necessary, in addition, to continue the discourse of the delusions for a uniformed voice is heard in the meaningless speeches of the patient; certain grammar rules apply to his words and they have certain sense. This grammar and this sense should be preserved so that the implementation of the phantasm in the surrounding reality would not seem to be a transition to another register, translation into a new language, a change in meaning.

The same language should sound but a new element of deduction should be introduced in its strict discourse. However, this element is not nearly indifferent; the delirium should not just be continued with its help but while continuing it a logical conclusion should be reached... Here, for example, there is a case with a patient who considered himself dead and actually was dying because he refused to eat; 'a group of people with pale faces and dressed as befits the dead enters his room, puts down a table, brings dishes with food and begins to eat and drinks in the sight of his bed. The dead tormented by hunger is looking at them; they express a surprise that he does not get out of bed and convince him that the dead actually eat no less than real people. He easily accostumes to this practice' (Foucault 1997: 330-331). 
Paradoxes of mental disorders are that in majority of cases patients' behavior is absolutely rational. For example, many of the things that a psychotic does are absolutely logical and he operates in accordance with a complex and thoroughly thought-over plan.

We can follow his reasoning for a lengthy period of time captivated by its clearity and perfectly correct logic until we run into certain inconsistency or a false belief ("I died"). However, in principle the gloominess and beliefs often go beyond the discourse of the mind. "Abnormality" is not inherent in the mind rather it might simply be a manifestation of a belief or an instinct, i.e. a state alien to rationality. In this sense, any sane person knowing that he will die but living as if it would never happen may adhere to the logic of the mind in everything but his basic disposition of "immortality" will be irrational in his case - it is simply goes beyond the bounderies of reason. Similarly, someone considering himself dead can also be in line with the demands of the mind; however, the primary premise of his actions would be irrational. Then two of these scenarios are not very different from each other. Rationality can serve the mind as well madness.

The fourth argument against the mind appeals to the problem of premislessness of the rational position - the mind cannot rely on itself and is not able to find reasonable bases in itself. The idea is that somewhere in the back of the mind there exists a belief in reason or a desire for the reason, or once accepted values, or, finally, a coercion to the reason but coercion ethical or ideological rather than apodictic. In the most general form this critical situation can be justified by the application of the principle of primordial faith, and only if it can be confirm that it (a belief) is the core of rational knowledge, criticism of rationality would be armed with one more important proof-point since knowledge and faith represent two incompatible categories. If a belief in faith is reasonable, then a belief in reason discredits the mind. In turn, attempts to justify reason through the mind lead nowhere. This impossibility is justified by the fact that since there is a choice (rational vs. irrational) there is freedom which could not have resulted from the rational where only single conclusion can be drawn from one premise. 
However, this choice does exist - one can either follow the path of rational or not. What causes a person to adhere to a rational viewpoint? Once the choice is made, each consequitive step is defined by reason but the soundness of the very first step is lost in the haze of meaningless tautologies, "I choose reason because it is reasonable..."

The fifth charge is expressed in the following statement: reason does not determine the final objectives. Kant's famous "purposefulness without purpose" or "purposiveness without purpose" (Kant 2007) provides the best description of the state of the mind as far as the distinction of goals is concerned. The mind has no problems with intermediate goals but as soon as the issue of ultimate objectives arises the mind gets confused. In some sense, it can be seen as yet another reason to point out that the mind is instrumental and to say that the mind is a deeply applied creature. The mind is most confident when major, large, ultimate goals are already set then it can rationally service them, however, this is as much as it can do. The core argument of postmodern philosophy in favor of the idea that reason was disqualified in the 20th century lies precisely in that - the classics led by the Enlightenment taught us to perceive reason not as a means but as an end goal. However, in fact, reason is a pure means and nothing more than that. Since this fact was largely disregarded, it had led to such terrible consequences in the 20th century.

Finally, the last reprimand to reason would be about its insensibility to morality. Rationality can successfully serve even most wicked ideas. Postmodernism draws a conclusion from insensibility of reason to morality about reason's underlying amorality as well as about the utopian nature of Socratic belief in the identity of rational and moral. In short according to some postmodern philosophers classical philosophy made a big mistake trying to justify the affinity of ethical and rational.

The most illumitive was perhaps the failure of Kant's attempt to justify morality from the platform of "reason alone". His theory received all kinds of reprimands from sarcastic irony inherent in the famous Schiller's epigrams to numerous charges of callousness and cruelty. However, critics of Kant whose position can be easily understood 
do not always take into account the insidiousness of the dilemma we are dealing with when deciding on what should serve as a guide of our moral actions - reason or feelings (moreover since a third option does not exist). What should substantiate our moral choices - the feeling of compassion, a sense of charity, a sense of beauty, a sense of pity or the feeling of love? Kant's answer is known and it is very categorical like his entire ethical theory - morality should never be based on feelings because they are transient and deceptive! Indeed, what could be more ephemeral and malleable than human sensuality! Here we are annoyed and offended and do not hesitate to do something we later regret. Or on the contrary we are experiencing a head-spinning feeling of love and we are more than ever complacent toward all mankind and are willing to forgive others or yourself that which we would never forgive under any other circumstances. Finally, virtuous deeds done only in a state of complacency or under a threat of punishment are seriously devalued in terms of their moral value. Kant believes that the morality of man and his ability to keep up the values cannot be entrusted to the senses - this ability is too precious and sensuality is too unreliable.

Based on these source data Kant has to make a harsh but justified conclusion - morality must be deaf to the voice of senses and must obey only reason. Subject's moral duty is a pure oughtiness because it is free from any sensible prerequisites but not free from the dictates of the reason which he complies with.

It is from this paragraph of Kant's great ethical program the part of the postmodern criticism of the mind the task of which was to permanently differentiate reason from morals begins.

Why is it that reason and morality are irrelevant to each other? Firstly, because it is reason that raises questions associated with the moral. The following questions can be asked only from a reasonable perspective: "What is morality?", "Why is morality obligatory?", "Why is morality moral?" However, it is well known that questioning of morality often leads to immorality. Equally, reasonable exploration of morality that gives rise to theories such as ethical utilitarianism, somewhat devalues human capacity for moral action. Kant understood that very well insisting on the autonomous and not heteronomous nature of morality. 
Secondly, as morality itself is unreasonable. When we attempt to analyze rationally any morality programs, we ultimately find: hidden ideologemes, irrational premises, unreflected mechanisms and so forth. Trying to filer the morality of anything superficial earlier or later we run into certain irreducible forms which do not service anything or anybody except themselves ${ }^{3}$. Encounters with these forms instigated a number of well-known post-classical concepts - the "will to power" (Nietzsche 1996), "the pleasure principle" (Freud, 1920), "the desire for recognition" (Hegel 1977, Kojeve 1980), etc. However, all these concepts are irrational at their heart.

Here we should add a few words about criticism of the autonomy of morality. The core statement of Kantian ethics is the rule that of autonomy of moral acts. An act is moral when it is driven strictly by the requirements of reason and by nothing else. A conclusion that follows from this statement is that reason itself does not serve anything anymore but is controlled strictly by itself. Otherwise, another conclusion would have been drawn from the statement - a moral act refers to reason and through reason to something else. However, since the mind is "instrumental," i.e. content-free and, therefore, always processes some external contents introduced to it, then it is not self-sufficient. In turn, self-sufficiency is a property of sensuality - self-sufficiency really serves only itself. A well known in psychoanalysis "pleasure principle" (Freud 1920) is based on genuine autonomy - it is meaningless to ask why we want something (this question is rational and automatically loses its sense when applied to the domain of desire). We want something just because we want it. However, Kant's categorical imperative is formulated in this particular way and pure oughtness - requirement of morality refers only to itself. It turns out that if the autonomous morality can exist, it must be based on sensuality. On the contrary, if it is based on reason, it must be, therefore, heteronomous.

The final verdict of this reasoning states that reason and morality are not fused as it was believed in classical philosophy and Enlightment. Their true disposition is such that they do not ever come

3 This was the Nietzschean principle of the "master's morality" - the morality, which serves only itself. 
in contact. They are not antagonistic to each other either but rather are just independent from each other and most probably would never come across each other. And then attempts to reduced human ethical responsibility only to the ability to continually and painstakingly "use the mind" would fail. Perhaps this is the most important concept that postmodernists wish to demonstrate. And this is what can be called the completing step of the program of critics of rationality.

In conclusion we will cite Horkheimer whose definition of the mind's "instrumentality" was used in the opening part of this paper. It seems that the following quotation confirms many issues we have discussed. "[...] Reasoning can now serve any purpose, be it evil or good. It is a tool of any social action; it cannot set standards of social or private life because standards are set by others. The mind is no longer seeking objective and universal truths for guidance; it deals with the tools which have already been provided for the set goals... Everything is determined by the 'system', in other words - by the power... the mind is completely enslaved by social process. Instrumental value the function of which is the domination over people and nature has become the only criterion" (Horkheimer 1997: 146).

\section{Conclusion: Dubium aude - Dare to doubt}

All this, in turn, brings about a change in nature of ideologies. The change consists in that as compared to the "classical times" namely, the time of Enlightenment - modern politics is deprived of equivalent means of resisting the ideological deception. The spirit of Enlightenment sought to reveal the true state of things, to uncover the mechanisms whose latent operation resulted in some pseudo-reality, which was passed off as a reality of the first order, while it was merely a reality of the second order, created and maintained by figures (not only by people, but also by anonymous structures) most successful in achieving their selfish goals in a medium where a specific ideological order prevailed. What was the most important for Enlightenment, though, was the fact that the forces whose deep-lying play gave rise 
to certain surface effects (social ideals and values, state priorities, national ideas and what we call public opinion) remained securely hidden from consciousness of outsiders or even from mediators of such forces themselves.

Modern societies feature somewhat different circumstances of interaction with ideology. From now on, origin of social and political products and their social nature will not be much of a secret either for their "producers" or for "end consumers". Citizens have a rather clear idea of how the political space is arranged, how and why ideologies exist, what forces represent whose interests etc. They may even understand that power, from time to time, misleads them. This sophisticated knowledge, however, does not make citizens more criticizing, and, knowing what ideological deception consists of, they are in no hurry to oppose it.

What, then, is left for opposition? It is clear that its stakes on "unmasking" will not pay off. "Unmasking" power does not mean breaking it down or disavowing it; de-sacralization does not work anymore as a means of demoralizing the enemy. Besides, if modern political reason is an educated reason, there is no need for power itself to hide its true motivation. It does not have to hide its "on the other side", since all this has long been unfolded "on this side", as a gesture of total knowledge and understanding of its citizens. In such a case, criticism of ideology will be blocked, since such criticism always pursues a sole goal, i.e. uncovering what is staying "off screen", the behind-the-stage games, the clandestine and the hidden. Yet, the problem is that such "uncovering" is part of the adopted rules of the game. Even irony, mockery or open scoffing at the falseness of power and ideology do not pose any threat for either power or ideology. With the opposition's strength depleted, irony can only simulate the distance of criticism; it just pretends occupying the transcendent place, whereas such irony is patronized by power as it is, and the latter, to whom human amusements are not alien, simply laughs at itself.

Thus, stability of modern ideology consists in that knowledge of the fact that "something is wrong" does not constitute a threat for the established system of relations, but is rather embedded in the foundation of such system from the very beginning. For P. Sloterdijk this circumstance gives an opportunity to change the Marxian definition 
of ideology as "false consciousness" to his own definition stating that "ideology is an educated false consciousness" (Zizek 1989: 267).

A modern oppositioner knows everything very well; he is sufficiently enlightened but for some reason remains dormant. The problem of modern societies, therefore, is not that it lacks Enlightment but that is lacks the will to act. Sloterdijk actually changes Marx's definition of ideology from the Christian version of "they do not know what they do" (Marx, 1990) to the modern post-ideological (and in this sense post-Enlightment) version: "they are well aware of what they do, but, nevertheless, doit" (Sloterdijk 1988: 43). But the very essence of the Enlightenment - the want of knowledge as if it were certain capital or a weapon providing means to counteract deception - gets eroded. Such oppositioner is, first and foremost, an individual integrated in the society. It is no surprise that his "rebellious" qualities are questionable: he is much too conformant struggle. Such condition of modern societies is defined by Sloterdijk, for example, as "universal and diffuse cynicism". Cynicism of the kind is not looking-and-mocking from the outside (which is characteristic of the Diogenes' kynicism) but is rather something common, ordinary, and, which is the main thing, legal. Modern criticism of social life is anything but asocial; instead, it is incorporated in the social routine without a tint of scandal or the revolutionism that has been so much poetized by romantics. A modern oppositionist "instinctively takes his mode of existence not as something evil and sneering, but rather as an involvement in the collective and realistically corrected opinion of things" (Sloterdijk 1988: 27), which means, of course, that he does not oppose the political realities, but, on the contrary, ensures their stability. In other words, criticism of power is hindered by absence, at the disposal of the criticism, of a self-contained system of values; oppositionists "feed" on the same meanings and social codes as the ordinary "man in the street".

Invulnerability of power is in its "transparency". In this respect, according to J. Baudrillard, "[...] transparency is something behind which nothing can be found, nothing can be detected, since there is simply nothing behind it. The system's strategy consists in assimilating its own substance. Where, then, can it be found? In terms of which law can we criticize it? How can anything 'Different' be constituted in relation 
to a system, which is nothing else but itself, equal to itself? Even if you do not accept it, you cannot become constituted into a 'Different'. This is really a problem, which we are living with now" (Baudrillard 2002: 69).

Thus, a modern oppositionist, who must endeavor to be "Different" with respect to the system, can neither work out nor make use of the resource of criticism: he is hindered by non-localized nature and uncalled-for friendliness of the enemy.

Therefore, roots of the anti-revolutionary spirit are so deep that the task of finding those who has not yet "integrated themselves" into the system becomes harder and harder. Perhaps, if anybody at all could perform a revolution both in minds and on barricades, these would be the outcast and the outsiders, i.e. those least involved in consumerist practices in the broader meaning of the word - those who demonstrate a non-standard way of thinking and way of life. The philosopher's task, in turn, will be to resist the power of commonly accepted meanings and to try to protect his discourse against trivialization and devaluation. To achieve this, the philosopher will have to always be in opposition - including opposition to opposition, but in no case on the side of the official ideology.

The above idea is best summarized by the statement by $\mathrm{H}$. Marcuse: "Modern industrial society is on its way to totality. By manipulating the demands through vital interests, it prevents the appearance of an efficient opposition to the whole (for totalitarianism gets along quite well with a 'pluralism' of parties, newspapers, 'control forces' etc.) The totalitarian nature of achievements of a well-developed industrial society leaves the theory of criticism without reasonable grounds for transcending such society. At the stage of its highest development, domination functions as administration; in super-developed countries of mass consumption, the administrated life becomes a standard of welfare for the whole - so that even oppositions unite in order to protect it. This is a pure form of domination. And, vice versa, its negation appears a pure form of negation. The theory of criticism by the society does not have, at its disposal, any notions that might throw a bridge across the abyss between its present and future; as long as it neither gives promises nor demonstrates success, it will remain negative" (Marcuse 1994: 121-146). 
This means that after all the expropriations of the revolutionary resource, after its structural "merger" with the dominant order, there should remain, nevertheless, some radical residual negativity - a fundamental, non-conceptual and non-bribable "no", which can still be opposed to everything else. This "value-added" negativity of a kind, with which one cannot come to terms, signifies zero degree of contentrichness: all it has to say is negation of the existing state of things. In is only under such conditions that it can retain its sovereignty: as a pure ability to oppose itself to the system.

It turns out that even if the Enlightenment wants to preserve itself, it can only attempt to do that at the cost of continuous criticism and doubts including questioning of its own strength and capabilities. Persistent mistrust to any knowledge statements, be they rational or irrational, should then be practiced whenever the Enlightenment is practiced. From now on none of the positive sets of values, norms and rules can be applied as criteria for evaluation of anything else. The Enlightenment is now stripped of any support as traps await for it everywhere. If reason is neutral and is ready to serve any values, if all existing values are already servicing the ruling order and, finally, and even if enlightened knowledge of what is wrong and where the deception lies does not stimulate action what is left to us? It seems that it would be something very unstable - to be always alert, not to trust, not to agree, to be uncooperative, to be suspicious of everything that seemed suitable for making the basis, i.e. basically to raise any cultural codes and meanings from the bottom and keep them in a suspended state, no matter how obvious they may appear. Only that which is nothing and is never obvious can become apparent. But for the said not to seem a repetition of well-known classical philosophy principles such as the famous Cartesian doubt as well as criticism praised by Kant, it should be understood that from now on we are talking about pointing weapons at themselves: rationality at the rationality, obviousness at the obviousness, enlightenment at the enlightenment. Distrust in the Enlightenment should now be inherent in the Enlightenment. It seems that this is exactly what Michel Foucault tries to tell us in his What is Enlightenment work when he writes, "I really believe 
that we can oppose the principle of self-criticism and permanent autonomous self-creation to that... topic" (Foucault 1984: 113).

In other words, the experience of the Enlightenment can only be preserved as an experience of the Anti-Enlightenment. "Dubium aude" - "Do not trust yourself" is, therefore, the motto of the Enlightenment. But how realistic and feasible is such a program? Is it possible to shape something constructive only out of criticism and mistrust including criticism and mistrust of the basics? And if we fear any constructiveness, isn't there a risk of sliding basically into a terroristic radicalism of denial of any order? All these questions apparently have yet to be answered and along those lines it should be mentioned that no matter what we think of the Enlightenment, the question concerning its status in the world today is still open and remains quite topical. Perhaps although the point is that this is the way it should be.

\section{Reference}

ADORNO, T. W.; HORKHEIMER, M. Dialectic of Enlightenment. Trad. Edmund Jephcott. Stanford: Stanford UP, 2002.

BAUDRILLARD, J. The transparency of evil, London: Verso, 1993.

MARCUSE, H. One-dimensional man: studies in the ideology of advanced industrial society. Boston: Beacon Press, 1964.

DESCARTES, R. 1960 Discourse on the method of rightly conducting one's reason and seeking Truth in the Sciences. Trad. Laurence J. Lafleur. New York: The Liberal Arts Press.

KANT, I. 'An answer to the question: what is enlightenment?' (1784), What is enlightenment? Eighteenth-century answers and twentieth-century questions. (Ed.) J. Schmidt. Berkeley: University of California Press, 1996.

KANT, I. Critique of judgement, Trad. James Creed Meredith. Oxford: Oxford University Press, 2007. 
KOJÈVE, A. Introduction to the reading of Hegel: lectures on phenomenology of spirit. (Ed.) Allan Bloom, Ithaca: Cornell University Press, 1980.

FOUCAULT, M. What is enlightenment? (Ed.) P. Rabinow. NY: Pantheon, 1984.

FOUCAULT, M. The history of madness in the classical age. (Ed.) Jean Khalfa. Trad. Jonathan Murphy and Jean Khalfa, New York: Routledge, 2006.

FREUD, S. Beyond the pleasure principle (C. J. M. Hubback, trans., 1922.). Trad. C. J. M. Hubback. London, Vienna: Intl. Psycho-Analytical, 1920; New York: Bartleby.com, 2010.

HEGEL, G. Phenomenology of spirit, Oxford: Clarendon Press, 1977.

HORKHEIMER, M. Critique of instrumental reason: lectures and essays since the end of WWII. Trad. M. O'Connell, New York: Seabury Press, 1974. p. 63-83.

LEVI-STR AUSS, C. Anthropologie structurale (1958), Structural Anthropology. Trans. Claire Jacobson and Brooke Grundfest Schoepf, 1963.

MARX, K. Capital, Volume I. London: Penguin Books, 1990.

NIETZSCHE, F. Beyond good and evil. Trad. Walter Kaufmann. New York: Random House, 1966.

NORRIS, C. 'What is enlightenment?' Kant according to Foucault, Cambridge Companion to Foucault. (Ed.) G. Gutting. NY: Cambridge University Press, 1994. p. 159-196.

PLATO. The Republic. Reeve, C. D. C. Plato. Indianapolis: Hackett, 2004.

SLOTERDIJK, P. Kritik der zynischen Vernunft (Critique of Cynical Reasoning); University Of Minnesota Press; 1 ed., 1988.

ZIZEK, S. The sublime object of ideology. Phronesis, 1989.

Received: 05/25/2016

Recebido: 25/05/2016

Approved: 06/03/2016

Aprovado: 03/06/2016 